\title{
eGovernance and Online Service Delivery in Estonia
}

\author{
Morten Meyerhoff Nielsen \\ United Nations University \\ Operating Unit on Policy-Driven Electronic Governance (UNU-EGOV) \\ Rua de Vila Flor 166, 4810-445 Guimarães, Portugal \\ meyerhoff@unu.edu
}

\begin{abstract}
Estonia's use of Information Communication Technology (ICT) in the public sector is regularly highlighted as an innovative model worth emulating. Despite this, research into the Estonian governance and inter-governmental cooperation model is limited, with most being 5-10 years old. In addition, recent literature reviews point to a limited understanding of technology use in public service delivery and the role played by governance, intergovernmental decision making and cooperation when introducing ICT solutions and online services to citizens.

As part of a larger qualitative, multi-country comparison, this article analyses the Estonian approach to electronic governance (eGovernance) and inter-governmental cooperation. Initial findings highlight the strength of the Estonian tradition of politically driven and motivated public sector modernisation, a consensus seeking and inter-governmental approach to eGovernment, trust between actors, the role of informal networks and cooperation with the private sector. The Estonian case thus supports academic arguments in favour of a strong eGovernance model and a high level of inter-governmental cooperation and decision making. While successful in relation to ICT infrastructure, standards, rollout to key enablers and internet voting (iVoting), the article highlights the potential benefits of formalising informal networks and streamline the governance model to minimize the risk of failure if consensus cannot be reached, if personal and institutional capacities and contacts does not exist.
\end{abstract}

\section{CCS Concepts}

- Information systems

\section{Keywords}

eGovernance; eGovernment; eService; use; inter-governmental corporation; evaluation; Estonia

\section{INTRODUCTION}

Two images are often associated with Estonia: pictures of the picturesque capital of Tallinn and articles on the innovative use of ICT (Information Communication Technology) in public administration. From internet voting (iVote), broadband access and government IT infrastructure, tech savvy business, innovation and the ability of non-Estonian residents to be electronic residents and set up their businesses in less than five minutes online, the ICT

Permission to make digital or hard copies of all or part of this work for personal or classroom use is granted without fee provided that copies are not made or distributed for profit or commercial advantage and that copies bear this notice and the full citation on the first page. Copyrights for components of this work owned by others than ACM must be honored. Abstracting with credit is permitted. To copy otherwise, or republish, to post on servers or to redistribute to lists, requires prior specific permission and/or a fee. Request permissions from Permissions@acm.org.

dg.o '17, June 07-09, 2017, Staten Island, NY, USA

(C) 2017 Association for Computing Machinery.

ACM ISBN 978-1-4503-5317-5/17/06 ..\$15.00

http://dx.doi.org/10.1145/3085228.3085284 successes are many. But how has a small middle income country in northern Europe seemingly succeeded where others have not?

From public administration (PA) [1-6], to information systems (IS) management [2, 3, 7-10], to electronic government and governance (eGovernment and eGovernance) [11-16], academics have highlight the failures of IT and technology use in the public sector. Mistakes include blindly digitising current processes [13, 16, 17], focusing on technology and supply [18-20] rather than valueadding outcome and impact of ICT $[4,21,22]$ - not only in relation to IT and technology use in public administration but even more so in relation to online services (eService) for citizens [20, 23].

Since the late 1999s, the so-called stage and maturity models have been the primary focus and tool for academic, private sector consultants and international organisations in assessing the relative success of countries in eGovernment and online public service delivery. Multiple authors - including Meyerhoff Nielsen's 2016 review of public sector reform, IT governance, and eGovernment literature [23] - finds that the current maturity models only address supply-side and technology issues, but do not fully understand public service delivery and production, and only a few organisational issues. Similarly, the maturity models and current research do not adequately address the role of governance and cooperation in ensuring the successful supply and use of online eServices. [8, 20, 23-25].

In fact, front-office service provision and back-office integration are mixed-up in numerous maturity models. One-stop shop portals do not constitute a form of transaction, but are an indicator of the degree in which authorities cooperate and integration in the provision and production of services via a portal [20, 23]. Heeks attempt to address this by proposing a two-dimensional matrix model distinguishing between the front- and the back-office [26]. Unfortunately, Heeks does not account for eGovernance or take-up [25].

Similarly, none of the analysed maturity models addresses governance directly [23, 25]. Davison [27], Iribarren et. al. [8], Janowski [28], Kalambokis et. al. [29], Shareef et. al. [30] and Waseda [31] models highlight management and coordination issues, such as the existence of chief information officers (CIO). Cooperation, on the other hand, is indirectly addressed in most models. This is manifested in terms of vertical and horizontal integration, and the existence of one-stop shops, the sharing of information and data between different authorities and levels of government - even private and third party stakeholders [25, 32, 33].

There is therefore a need to look at eGovernance and intergovernmental cooperation in isolation from the mechanisms of public service delivery and how ICT is used in this regard. While eGovernment refers to "the use of ICT and its application by government for the provision of information and public services to the people" [34], eGovernance comprises the processes of governing, whether undertaken by a government, market forces, social networks (e.g., families, tribes, professionals), formal or informal organisations, a geographical territory, or via laws, norms, 
power, or language [34]. Thus, eGovernance refers to the governing bodies responsible for the successful introduction of eGovernment solutions like online public services. By comparison, cooperation refers to activities engaged by various parties toward a shared purpose.

To cast light on the role of eGovernance and inter-governmental cooperation in the successful supply and citizen use of eServices, this article presents and analyses the often mentioned and influential Estonian case. The aim is two-fold: to identify the Estonian features and lessons learned in relation to the role of eGovernance and inter-governmental cooperation and to add the Estonian lessons to a future cross-country comparison.

The article is structured as follows: the methodology and conceptual framework for the case is outlined (section 2), the Estonian context and case is presented in relation to the conceptual framework including background indictors and preconditions (section 3), the national approach to governance, cooperation model and eGovernment (section 4), key enablers and services in place, effect measurements and achievements (section 5), before the discussion and conclusions are presented (section 6).

\section{METHODOLOGY}

To address the research gaps in relation to eGovernance and intergovernmental cooperation [23], a classical exploratory, qualitative, multi-country case study methodology framework [35-37] is applied to enable a with-in case analysis.

An adapted version of Krimmer's context, content, process model (CCP model) [28] is used as it provides a framework for the individual cases across four relevant macro-dimensions: Background socio-economic indictors (section 3.1) and ICT related pre-conditions (section 3.2); national governance and cooperation model (section 4.1); national approach to eGovernance and eGovernment (section 4.2); and effect measurements (section 5). Each dimension explains a key area that influences processes, choices and outcomes in relation to eService supply and take-up. Using the framework for the with-in case analysis help isolate the eGovernance and inter-governmental cooperation mechanisms in play and to draw out specific aspects and lessons.

The consistent application of the conceptual framework across multiple cases allows for the future cross-country comparison to determine the correlation (i.e., the more of $\mathrm{Y}$, the more $\mathrm{X}$ ) between a strong cooperative eGovernance model (cause) and the introduction of online services (effect 1 ) and subsequent citizen use of the online service delivery channel (effect 2).

Using the conceptual framework, this article identifies Estonia's respective strengths and weaknesses in relation to the country's approach to eGovernance and its eGovernment experiences since 1991, but with a particular focus on the period since 2010 .

Estonia has been chosen for three main reasons: it is an often cited and is an influential example of successful government use of ICT and online public service delivery; it is a small, centralized, middleincome country complimenting the Faroese [38], Danish [39], Georgian [40], and Japanese cases [41] analysed by the author, but is also a relatively under-analysed governance model [35, 37, 42].

Primary sources used include relevant academic literature and international references from EU and OECD, relevant policy documents, national and international statistical sources, e.g. Eurostat [43] and International Telecommunications Union (ITU) [44] and UNDESA's eGovernment Readiness Index [34, 45, 46].

\section{BACKGROUND}

As a result of history and culture, countries operate in different contexts and offer different perspectives and experience when it comes to online service provision for citizens. Similarly, population size, income levels, administrative systems and complexity of these systems varies. It is therefore important to put things in context.

\subsection{Socio-economic background}

Estonia is, in socio-economic terms, a small and sparsely populated country. While an OECD member - the first former communist country to gain membership - it is a middle-income country. Estonia is an open-export orientated economy with productivity and GDP growth and a start-up mentality. Considered a nation state with a strong identity, Estonia also has a large Russian-speaking minority and an ageing population (due to immigration and low birthrates) [47]. For details see key statistics in Table 1.

Table 1. Key socio-economic statistics 2016 [47]

\begin{tabular}{|l|l|}
\hline Population & $1,258,545$ (July 2016 est.) \\
\hline Territorial size & $1.399 \mathrm{~km} 2$ \\
\hline Population density & 34 per km2 \\
\hline Official languages & Estonian \\
\hline Ethnic groups & $\begin{array}{l}\text { Estonian } 68.7 \%, \text { Russian } \\
24.8 \%, \text { Ukrainian } 1.7 \%, \\
\text { Belarusian } 1 \%, \text { Finn } 0.6 \%, \\
\text { other } 1.6 \%, \text { unspecified } 1.6 \% \\
(2011 \text { est.) }\end{array}$ \\
\hline $\begin{array}{l}\text { Median age and life } \\
\text { expectancy }\end{array}$ & $\begin{array}{l}42.4 \text { and } 76.7 \text { years } \\
\text { Population growth }\end{array}$ \\
\hline Urbanization & $-0.54 \%$ \\
\hline GDP 2015 (est.) & $67.5 \%$ \\
\hline GDP per capita 2015 (est.) & $€ 25,433.46$ \\
\hline Unemployment 2015 (est.) & $6.2 \%$ \\
\hline $\begin{array}{l}\text { Imports 2015 (est.) } \\
\text { Exports 2015 (est.) }\end{array}$ & $\begin{array}{l}€ 12.52 \text { billion } \\
€ 11.62 \text { billion }\end{array}$ \\
\hline
\end{tabular}

\subsection{Internet access and use}

For online service delivery to succeed, internet access and a minimum level of digital literacy and competences are essential pre-conditions. As an indicator of the level of digital literacy, the actual use of the internet, online banking and shopping sites are used (eBanking and eCommerce, respectively). To put Estonia in context, average for the EUs 28 member states is include in Table 2.

Table 2. Individual and household access to, and use of the internet, 2010-2016, selected years (EU28 country average in brackets) $[43]$

\begin{tabular}{|l|c|c|c|}
\hline & 2010 & 2013 & 2016 \\
\hline $\begin{array}{l}\text { Household } \\
\text { internet access }\end{array}$ & $67 \%(70 \%)$ & $79 \%(79 \%)$ & $85 \%(86 \%)$ \\
\hline $\begin{array}{l}\text { Individual with } \\
\text { mobile internet }\end{array}$ & $\begin{array}{l}33 \%(21 \%) \\
(2011 \text { data) }\end{array}$ & $33 \%(24 \%)$ & $26 \%(27 \%)$ \\
\hline
\end{tabular}




\begin{tabular}{|l|l|l|l|}
\hline $\begin{array}{l}\text { Individual using } \\
\text { the internet (at } \\
\text { least once a } \\
\text { week) }\end{array}$ & $71 \%(65 \%)$ & $77 \%(72 \%)$ & $85 \%(79 \%)$ \\
\hline
\end{tabular}

Data shows that the vast majority of Estonian households choose to pay for internet access and that most Estonians are online almost daily. The key pre-conditions for introduction online government services and citizens subsequent use of them therefore exist in Estonia.

\section{4. eGOVERNMENT AND GOVERNANCE}

Public sector use of ICT has been actively pursued in Estonia since independence in 1991. A political willingness to innovate, work with the private sector and transform the public sector has been key [48-51]. The strategic focus and governance model in place is therefore helpful for understanding the Estonian context and eGovernment outcomes.

\subsection{Strategic focus since 1991}

The Estonian eGovernment focus has consistently focused on five core areas. The first two, infrastructure such as affordable internet availability and digital literacy are essentially preconditions for any form of large scale digital transformation, information society and digital economy. The next three includes: electronic identification (eID), which contains the secure authentication of users by digital certificates embedded in ID or SIM cards; digital information covers information systems and databases at all levels of government, and lastly the formalized exchange of content through the X-road data exchange service layer for connected databases [52, 53]. Over time the importance and strategic emphasis has naturally shifted, as described in Table 3.

Table 3. eGovernment in Estonia, 1998-2020 [52-55]

\begin{tabular}{|l|l|}
\hline $\begin{array}{l}\text { 1998-2003 } \\
\text { Esinciples of the } \\
\text { Information Policy }\end{array}$ & $\begin{array}{l}\text { The first eGovernment strategy focus on } \\
\text { the: promotion and entrenchment of } \\
\text { democracy, development and roll-out } \\
\text { government ICT infrastructure; increase } \\
\text { competitiveness esp. through de- } \\
\text { monopolisation; increase the speed post- } \\
\text { Soviet property restitution, develop } \\
\text { eCommerce and eBanking; sustaining } \\
\text { Estonian culture and language, and; } \\
\text { improve State defence utilising ICTs. }\end{array}$ \\
\hline $\begin{array}{l}\text { Estonian } \\
\text { Information }\end{array}$ & $\begin{array}{l}\text { Aligned to the EU Europe 2002 and } \\
\text { 2005 action plans the objectives incl.: } \\
\text { introduction and promotion of citizen, } \\
\text { business and intra-government } \\
\text { eServices; roll-out of ID-card (incl. eID); } \\
\text { promote internet access and use through } \\
\text { training (incl. reaching EU average, 1 PC } \\
\text { per 20 students in schools); increase } \\
\text { public sector productivity though ICT } \\
\text { (incl. document management and } \\
\text { archiving, improved registries and data, } \\
\text { launch of X-road); economic growth and } \\
\text { export capacity of the ICT sector; } \\
\text { promote ICT security, and; international } \\
\text { promotion and improved "eGovernment } \\
\text { position". }\end{array}$ \\
\hline $\begin{array}{l}\text { Estonian } \\
\text { Information }\end{array}$ & $\begin{array}{l}\text { Closely aligned to the EU i2010 } \\
\text { eGovernment Action Plan the focus is on } \\
\text { infrastructure underpinning the }\end{array}$ \\
\hline
\end{tabular}

\begin{tabular}{|c|c|}
\hline $\begin{array}{l}\text { Society Strategy } \\
2013\end{array}$ & $\begin{array}{l}\text { promotion of a knowledge-based society } \\
\text { and economy. Objectives incl.: multi- } \\
\text { channel service delivery, WCAG } \\
\text { compliance of government websites, } \\
\text { more transparent and user-centric } \\
\text { eService's; improve digital literacy with } \\
70 \% \text { of Estonians using the internet; } \\
80 \% \text { user satisfaction for citizens and } \\
95 \% \text { for business; } 15 \% \text { of GDP is } \\
\text { generated by the ICT sector and } \\
\text { productivity levels are at least } 75 \% \text { of } \\
\text { the EU average. Separate broadband and } \\
\text { cyber security strategies were launched } \\
\text { in } 2011 \text { and } 2012 \text { respectively, as well as } \\
\text { for local government (2008-2011), a } \\
\text { programme for increased awareness } \\
\text { (2007-2011) }\end{array}$ \\
\hline $\begin{array}{l}\text { 2014-2020 Digital } \\
\text { Agenda: Estonian } \\
\text { Information } \\
\text { Society Strategy }\end{array}$ & $\begin{array}{l}\text { Focus on: smart solutions and enabling } \\
\text { infrastructure such as, } 100 \mathrm{mb} \text { per second } \\
\text { internet country wide; } 60 \% \text { of Estonians } \\
\text { use the internet daily; } 20 \% \text { of the } \\
\text { population use eID/eSignature; update } \\
\text { eService usability standards and } \\
\text { uniformity across government; provide } \\
\text { technical and organisational } \\
\text { infrastructure for citizens to use and } \\
\text { control their personal data; increase } \\
\text { cross-border cooperation on data } \\
\text { exchange, eID, eSignature etc.; promote } \\
\text { eResidency, and; improve policy and } \\
\text { decision making framework. Health care } \\
\text { (2014-2020), education, business } \\
\text { environment and cyber security (2014- } \\
\text { 2017) are set out in other strategies. }\end{array}$ \\
\hline
\end{tabular}

Policy wise, Estonia is an early mover, launching its first eGovernment related strategy in 1998. Related eGovernment legislation is found to be introduced neither earlier nor in a distinctly different form or quality than other central and easternEuropean countries $[48-50,56]$. The initial strategies are closely aligned to the 2000 Lisbon Agenda and EU policies aiming to make Europe the most competitive knowledge and information society in the world by 2010 . The focus has very much been on infrastructure roll-out, key enablers and use including broadband access, digital literacy, backend IT systems, eID, eSignature, iVoting and the supply of online services. Since 2014, the use of eServices and usercentricity, artificial intelligence, data and once-only principles, eParticipation and the governance model - all have traditionally received relatively little strategic attention - are in focus.

Historically, Estonia has spent a minimum of $1 \%$ of the annual budget on ICT and information society related activities [48, 51]. More than $€ 62.6$ million were spend in the period 2007-2013 and $€ 200+$ million is expected for the Digital Agenda 2014-2020 [52, 55]. Interestingly, an estimated $85 \%$ of government spending on ICT comes from EU Structural Funds [52]. The use of EU funding as provided the necessary investments by an otherwise cash strapped government, especially in the first decade of post-Soviet independence. The use of EU funds is possible due to the close alignment between European and Estonian strategic objectives in the eGovernment. The strategic alignment of early strategies to EU policies is a natural consequence of the 1991 independence from the Soviet Union, the political drive for an ICT supported modernization of the public administration, facilitating growth in 
an already established technology sector and promise of future EU membership [48, 49, 51].

The Estonian strategic focus on infrastructure roll-out, accessibility, digital literacy, standards, key enablers, backend systems, and subsequently eService supply and subsequently takeup reflects similar patters seen in Europe, the former Soviet Union and beyond (albeit at different pace) [34, 41, 45, 46, 53, 57-60].

\subsection{Governance model and institutional framework}

Estonia is in many ways a small and highly centralized country. The central government institutions are few and provide most public services for citizens. The country has no regions as such, and its counties do not provide any citizen services of note. Except the four main urban centers (Tallinn, Tartu, Narva and Pärnu), local authorities have limited capacities and provide only a few services. This is not expected to change despite the 2017 structural reform of local government, which will merge 183 rural municipalities, often with less than 3,000 inhabitants, and 30 city municipalities. While the guided minimum is 5,000 but ideally 11,000 inhabitants [61] the new municipalities will continue to have limited financial and human resources to provide more than limited portfolio of citizen services, let alone any number of online services. Table 4 summarises the general approach to public service delivery in Estonia.

Table 4. General governance and institutional framework [53, $54,62]$

\begin{tabular}{|l|l|}
\hline & Estonia \\
\hline $\begin{array}{l}\text { National } \\
\text { institutional } \\
\text { framework and } \\
\text { governance }\end{array}$ & $\begin{array}{l}\text { Centralized. Small size of country, } \\
\text { service delivery and ICT related issues } \\
\text { concentration on a few key national } \\
\text { ministries and agencies. High number of } \\
\text { municipalities with limited service } \\
\text { delivery capacities. }\end{array}$ \\
\hline $\begin{array}{l}\text { Decentralisation of } \\
\text { government } \\
\text { authority }\end{array}$ & $\begin{array}{l}\text { Limited, due to small size of country, } \\
\text { high number of municipalities with } \\
\text { limited capacities. }\end{array}$ \\
\hline
\end{tabular}

Like governance in general, Estonia's approach to ICT reflects the country's context, experience and public sector capacities, including decision making processes, the degree of cooperation between authorities and different levels of government, the private sector, civil society and research community.

Politically, Estonian policy has since 1991 been dominated by a center-right laissez-faire attitude to the role of government and public finances, but simultaneously been influenced by the Nordic approach and welfare model. The result has been a relatively small public administration, a focus on public private partnerships, outsourcing, a high level of fluidity between the public and private spheres, consensus seeking and a high level of trust [48, 49, 51].

Historically, policies, strategies, action plans and institutionalized processes have often been fragmented or lacking. Focus has been on implementation rather than on formal processes or system documentations - exemplified the overly complex pre-2014 eGovernance organigram in Figure 1 [49, 54, 62]. The success of Estonia has been based on the political vision and willingness to innovate, replace legacy systems, scrap old processes and legislation. This has been facilitated by the informal networks, personal contacts and trust which characterize Estonia's public sector [49-51].

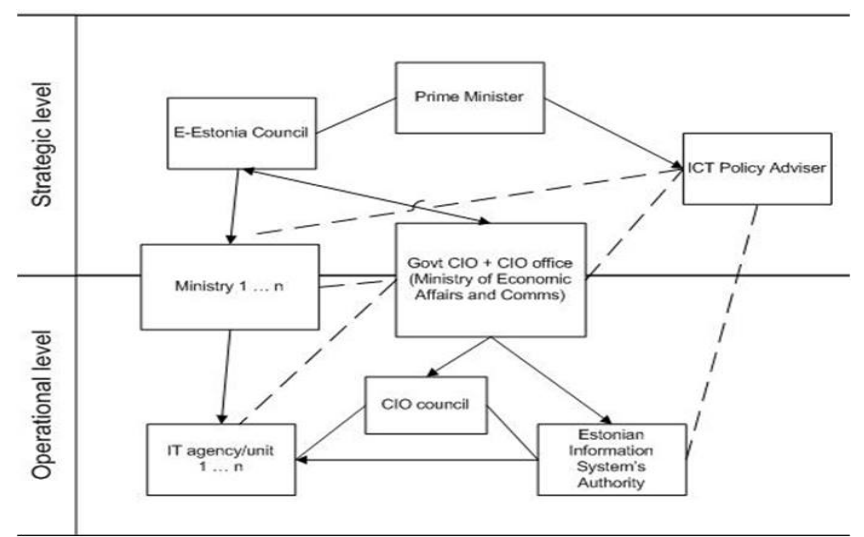

Figure 1. Pre-2014 eGovernance and coordination model [63] (Note: Full and broken lines represent formal and informal network structures, respectively)

Table 5 summaries the Estonia approach to ICT and its governance set-up introduced with the 2014-2020 Digital Agenda.

Table 5. eGovernance and cooperation actors and responsibilities [52-54, 64]

\begin{tabular}{|l|l|}
\hline $\begin{array}{l}\text { Responsible } \\
\text { authority for } \\
\text { eGovernment } \\
\text { strategy }\end{array}$ & $\begin{array}{l}\text { On the strategic level, the Information } \\
\text { Society Council (ISC) (sometimes } \\
\text { known as the e-Estonia Council) is } \\
\text { chaired by the Prime Minister and } \\
\text { provides the strategic vison, direction } \\
\text { and overall horizontal and vertical } \\
\text { coordination. } \\
\text { On the operational level, the Ministry of }\end{array}$ \\
\hline $\begin{array}{l}\text { Economic Affairs and Communication } \\
\text { (MKM) is the mandated and regulatory } \\
\text { authority, with a dedicated Department } \\
\text { of State Information Systems (RISO) for } \\
\text { initiating, coordination, monitoring and } \\
\text { auditing the strategy. The national } \\
\text { (e)government CIO and office is also } \\
\text { housed in the MKM. }\end{array}$ \\
\hline $\begin{array}{l}\text { Responsible } \\
\text { authority for } \\
\text { action plan }\end{array}$ & $\begin{array}{l}\text { On the strategic and operational level, } \\
\text { MKM and RISO is responsible for } \\
\text { initiate, drafting, coordinating and } \\
\text { and action plans } \\
\text { monitoring the action plan, but is } \\
\text { accountable to the ISC for strategic } \\
\text { direction and horizontal coordination (if } \\
\text { so required). } \\
\text { MKM/RISO is supported by thematic } \\
\text { work groups and networks which are } \\
\text { formed to coordinate individual action } \\
\text { plan initiatives on a daily basis (in line } \\
\text { ministries etc.). }\end{array}$ \\
\hline $\begin{array}{l}\text { MKM and RISO is responsible and } \\
\text { mandated to initiate and coordinate new } \\
\text { strategies and action plans but must } \\
\text { follow the direction given by the ISC. } \\
\text { MKM/RISO is supported by thematic } \\
\text { work groups and networks which are } \\
\text { formed to coordinate individual action } \\
\text { plan initiatives daily (in line ministries } \\
\text { etc.). }\end{array}$ \\
\hline
\end{tabular}




\begin{tabular}{|c|c|}
\hline $\begin{array}{l}\text { Chairperson } \\
\text { organisation }\end{array}$ & $\begin{array}{l}\text { Prime Minister chair the ISC and is } \\
\text { supported by the vice-chair, the Minister } \\
\text { for MKM. }\end{array}$ \\
\hline $\begin{array}{l}\text { Hosting } \\
\text { organisation and } \\
\text { secretariat }\end{array}$ & $\begin{array}{l}\text { Prime Minister's office, supported by } \\
\text { MKM/RISO. }\end{array}$ \\
\hline $\begin{array}{l}\text { Member } \\
\text { organizations }\end{array}$ & $\begin{array}{l}\text { Prime Minister's Office, MKM, national } \\
\text { CIO, Ministers of Entrepreneurship, } \\
\text { Minister of Education and Research, } \\
\text { Minister of Public Administration, } \\
\text { Estonian Association of IT and } \\
\text { Telecommunication. Other ministers and } \\
\text { representatives invited if relevant. }\end{array}$ \\
\hline $\begin{array}{l}\text { National } \\
\text { governance and } \\
\text { cooperation model }\end{array}$ & $\begin{array}{l}\text { Hybrid model, i.e. centralized in relation } \\
\text { to strategy and policy development, but } \\
\text { decentralized and uncoordinated in } \\
\text { relation to municipalities - not } \\
\text { represented in the ISC or in } \\
\text { MKM/RISO. } \\
\text { MKM/RISO has the regulatory } \\
\text { responsibility for eGovernment } \\
\text { including initiating, drafting, } \\
\text { coordinating, monitoring strategy, action } \\
\text { plan, legislation, budget etc., with } \\
\text { Department of Information Society } \\
\text { Service Development (ITAO) providing } \\
\text { service quality standards and channel } \\
\text { strategies and the Estonian Information } \\
\text { Systems Authority (RIA) responsible for } \\
\text { the national portal www.eesti.ee, the } \\
\text { Public Key Infrastructure (PKI), EEBone } \\
\text { network, State information system, X- } \\
\text { road data exchange, some legal aspects. }\end{array}$ \\
\hline $\begin{array}{l}\text { Process of } \\
\text { eGovernment } \\
\text { strategy and action } \\
\text { plan development } \\
\text { and approval } \\
\text { (from idea to } \\
\text { approval by } \\
\text { government) }\end{array}$ & $\begin{array}{l}\text { Centralized, initiated and coordinate by } \\
\text { RISO, but hybrid as MKM/RISO is } \\
\text { responsible to the ISC which provides } \\
\text { the vision and strategic direction. Intra- } \\
\text { ministerial co-operation group provides } \\
\text { input to ensure stronger links between } \\
\text { the ICT policy and other national } \\
\text { policies that influence the development } \\
\text { of the information society (e.g. } \\
\text { entrepreneurship and education policy). } \\
\text { Additional input from the work groups } \\
\text { of the Information Technology and } \\
\text { Telecommunication Association and the } \\
\text { eGovernance Academy. }\end{array}$ \\
\hline $\begin{array}{l}\text { eGovernment } \\
\text { strategy legality }\end{array}$ & $\begin{array}{l}\text { Yes, partially, as part of the government } \\
\text { programme. }\end{array}$ \\
\hline $\begin{array}{l}\text { Action plan (i.e. is } \\
\text { the strategy } \\
\text { underpinned by an } \\
\text { action plan) }\end{array}$ & $\begin{array}{l}\text { Yes, but generally in 2-year intervals and } \\
\text { adjusted annually. KPIs been introduced } \\
\text { with the Digital Agenda 2014-2020. } \\
\text { From } 2015 \text { underpinned by the } \\
\text { mandatory provision of a business case } \\
\text { analysis for ICT initiatives budget } \\
\text { approval. }\end{array}$ \\
\hline $\begin{array}{l}\text { Action plan } \\
\text { legally binding }\end{array}$ & No. \\
\hline
\end{tabular}

As outlined in table 5, the Estonian eGovernance and intergovernmental cooperation model retain a relative level high level of complexity. It can nonetheless be boiled down to three layers: The strategic level, the operational level and the daily implementation level.

At the strategic level the eGovernment strategic direction and vision is defined by the Prime Minister, the Minister of MKM - in practice the mandated and responsible authority for eGovernment - the national $\mathrm{CIO}$, key ministers and stakeholders from the private sector within the ISC. Key responsibilities include: discussing and approving the draft and final strategy, action plans, terms of reference, draft and approve policy and legislation, and; regular and final evaluation and monitoring reports incl. EU Structural Funds use on ICT [52, 53, 55].

At the operational level, MKM and RISO are key. Their roles were redefined with the 2014-2020 Digital Agenda. While individual authorities are responsible for the actual implementation and daily management of programmes and projects, this is supported by the CIO network. The aim is to ensure everyday cooperation in the execution of activities laid down in the national eGovernment strategy and action plan. The CIO network is led and hosted by RISO, while members include relevant officials responsible for the ICT development in all ministerial areas, as well as the representatives of local authorities and the ICT sector. The CIO network is responsible for the overall coordination, cooperation, conflict resolution and exchange of information related to ICT projects and action plan initiatives. MKM/RISO and the CIO network may establish thematic or task-based work groups and networks if required by the deemed necessary to a successful implementation of the action plan or if required to ensure the individual programmes and projects are coordinated appropriately. MKM/RISO may also initiate bilateral or multilateral meetings with ministries to harmonise the execution of sectoral strategies with ICT components (e.g. in education and healthcare) which are not covered by the eGovernment strategy and action plan. $\mathrm{MKM} / \mathrm{RISO}$ may also agree or report on actions laid down in the work programme and can escalate issues to the ISC [49, 53-55].

While not illustrated in the pre-2014 eGovernance organigram in Figure 1, the daily implementation has always been decentralized to responsible line-ministries and authorities. From 2014, a coordination mechanism has been introduced in the form of thematic or task-based work groups and networks (e.g. records management council, expert group on interoperability, etc.). Each thematic work group and network is responsible for the implementation of their respective action plan initiatives and report to the CIO network on progress, risks and for potential conflict resolution. That said, it is not clear if the individual networks can escalate unresolved issues to the CIO network or MKM/RISO, and who in turn may escalate issues to the ISC. While thematic work groups and networks report to the national $\mathrm{CIO}$ network, their number and focus is decided by either the CIO network itself, the MKM, the ISC or the government cabinet (based on proposals from the Council or the Minister) [55].

With the 2014-2020 Digital Agenda, a vision-network has been introduced in Estonia. The role of the vision-network is to identify new trends and patterns at home and abroad, monitor and recommend adjustments to achieve the national eGovernment and information society vision across government and all sectors. The vision-network consists of invited key opinion makers and experts from the public and private sector, academia, and civil society. The vision-network generally exchanges ideas and works on an ad hoc basis. The vision-network is hosted jointly by the ISC and the MKM [55]. The relationship between the national CIO (embedded 
in MKM and a member of the ISC) and RISO is unclear, but there seems to be a division of labour, with the CIO focusing on the eResidency programme and international corporation. The model is summarised in Table 6 and illustrated in Figure 2 below, and also illustrates the overlapping authority and mandates for implementation of the action plan and initiatives, coordination in relation to the eGovernment strategy and the wider areas of the information society.

Table 6. eGovernance and coordination model since 2014 [55]

\begin{tabular}{|c|c|c|}
\hline & $\begin{array}{c}\text { Co-ordination of } \\
\text { the } \\
\text { implementation of } \\
\text { strategy }\end{array}$ & $\begin{array}{c}\text { Wider co- } \\
\text { ordination of the } \\
\text { development of } \\
\text { information } \\
\text { society }\end{array}$ \\
\hline Vision & $\begin{array}{c}\text { Information } \\
\text { Society Council }\end{array}$ & Vision networks \\
\hline Strategy & $\begin{array}{c}\text { Information } \\
\text { Society Council } \\
\text { and } \\
\text { MKM / RISO }\end{array}$ & Detween ministries \\
\hline $\begin{array}{c}\text { Implion plans } \\
\text { implementation } \\
\text { and everyday work }\end{array}$ & $\begin{array}{c}\text { CIO network and } \\
\text { Thematic work } \\
\text { groups / networks }\end{array}$ & \\
\hline
\end{tabular}

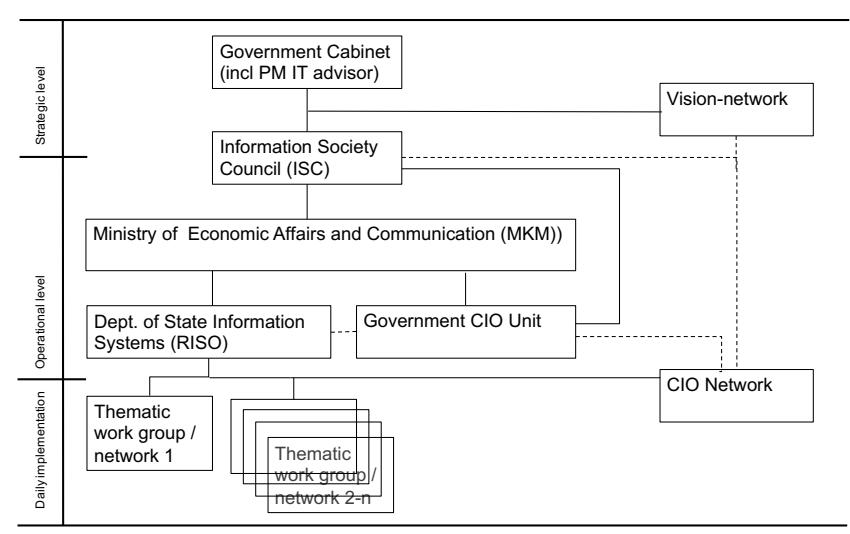

Figure 2. eGovernance and coordination model (by author)

(Note: Full and broken lines represent formal and informal network structures, respectively)

\section{KEY ENABLERS, CITIZEN ESERVICES, THEIR USE AND IMPACT}

Having confirmed that the required infrastructure and digital literacy exists (section 3), outlined the strategic eGovernment focus over time and described the governance and cooperation model (section 4), what has Estonia achieved in terms of the roll-out (supply) of key enablers and citizen eServices, actual outcomes and impact (i.e. demand and use)?

The availability and use of eIDs, digital signatures and eServices constitutes an effect and impact measurement of eGovernment activities but also the efficiency and effectiveness of the eGovernance model applied and the level of inter-governmental cooperation. eIDs and digital signatures are important as key enablers for government provision of more advanced online service provision such as personal and proactive service provision and not least citizens eService. They allow for the secure and reliable identification of individuals, secure completion, submission and storage of information and data provided during an online transaction, and the legally binding signature of electronic documents and transactions. The type and number of service areas in a country vary depending on a natural context or a given service areas. To trace the impact over time and in real terms, and allow for the future cross-country comparison, the EU 12 benchmarking citizen service is used as a basis for the effect measurement. The EU benchmark consists of high-frequency, high-volume services, relevant in most national contexts and to a majority of citizens or specific target groups.

The existence of key enablers, such as eIDs, digital signatures and various eService's is relatively easy to verify through the national one-stop portal (www.eesti.ee) and relevant government websites. The role of early EU wide strategies and action plans (i.e. the 2000 Lisbon Agenda, Europe 2002 and 2005, i2010 and later Europe 2020) should not be underestimated and means that 12 citizens and 8 business orientated, high-volume, high-frequency (some may say universal services) are available online in most European countries, including Estonia. The existence of eID/eSignature, digital post box solutions and a few select number citizen service areas are confirmed in Table 7.

Table 7. Individual use of the internet 2014-2016, selected years

\begin{tabular}{|c|c|c|c|c|}
\hline & \multirow[t]{2}{*}{$\begin{array}{c}\text { eService } \\
\text { availability }\end{array}$} & \multicolumn{3}{|c|}{$\begin{array}{c}\text { Degree of digitization (i.e. \% } \\
\text { of service delivery volume } \\
\text { online) }\end{array}$} \\
\hline & & $\begin{array}{c}201 \\
0\end{array}$ & $\begin{array}{c}2013 \\
(2015)\end{array}$ & 2016 \\
\hline $\begin{array}{l}\text { eID/eSignat } \\
\text { ure [65] }\end{array}$ & Yes & & & $\begin{array}{c}1,277,786 \\
”\end{array}$ \\
\hline $\begin{array}{l}\text { Digital post } \\
\text { [66] }\end{array}$ & Yes & & $\begin{array}{c}(255,669 \\
)\end{array}$ & 294,689'”' \\
\hline $\begin{array}{l}\text { Tax } \\
\text { declaration } \\
{[67]}\end{array}$ & Yes & $92 \%$ & $\begin{array}{l}92 \% \\
(96 \%)\end{array}$ & $96 \%$ \\
\hline $\begin{array}{l}\text { Register for } \\
\text { school [68] }\end{array}$ & Yes* & & & 670.054 \\
\hline $\begin{array}{l}\text { Register for } \\
\text { university }\end{array}$ & Yes** & & & \\
\hline $\begin{array}{l}\text { Apply for } \\
\text { student } \\
\text { grant }\end{array}$ & Yes & & & \\
\hline $\begin{array}{l}\text { Change of } \\
\text { address [66] }\end{array}$ & Yes & & $(75,719)$ & 81,919 \\
\hline $\begin{array}{l}\text { Housing } \\
\text { subsidy }\end{array}$ & Yes\# & & & \\
\hline $\begin{array}{l}\text { Apply for } \\
\text { pension }\end{array}$ & Yes\# & & & \\
\hline $\begin{array}{l}\text { Report } \\
\text { vermin } \\
\text { (FixMyStr) }\end{array}$ & No & & & \\
\hline Report theft & No & & & \\
\hline
\end{tabular}


"N. of active cards. "'No. of redirections to other mail servers. All ID numbers have a digital post box on eesti.ee. *Depends on municipality. **Depends on university. \#Multiple service types from different authorities, not all transactional eServices.

What is harder to assess is the actual volume of public service delivery online - or degree of digitization (i.e. \% of service delivery volume online). Where available, the degree of digitization is included in Table 7.

Available data shows that the vast majority of Estonians have activated and use their eID and digital signatures, almost all tax returns are pre-filled and approved by citizens online, most children are registered for primary and secondary school online and that many change their addresses online too. By contrast to the successful introduction and high usage of eServices in some service areas, others such as social benefits and municipalities service are fragmented, not available as a transaction service online or not widely used [49, 53, 54, 56, 62]. Similarly, both citizens and authorities seem unaware of the potential efficiency by sending messages digitally via the joint-governmental digital post infrastructure provided by www.eesti.ee.

Considering the limited data availability for eService use, statistics for the proportion of citizens use of online banking (eBanking), shop online (eCommerce) and their level of online interaction with public authorities is a useful substitute and presented in Table 8.

Table 8. Citizens use of eBanking, eCommerce and interaction with public authorities online (at least once per year) 20102015, selected years (EU28 country average in brackets) [43]

\begin{tabular}{|l|c|c|c|}
\hline Online banking & 2010 & 2013 & 2016 \\
\hline Online commerce & $\begin{array}{c}65 \% \\
(36 \%)\end{array}$ & $\begin{array}{c}72 \% \\
(42 \%)\end{array}$ & $\begin{array}{c}79 \% \\
(49 \%)\end{array}$ \\
\hline $\begin{array}{l}17 \% \\
(40 \%)\end{array}$ & $\begin{array}{c}23 \% \\
(47 \%)\end{array}$ & $\begin{array}{c}56 \% \\
(55 \%)\end{array}$ \\
\hline $\begin{array}{l}\text { Interacted with } \\
\text { government online }\end{array}$ & $\begin{array}{c}50 \% \\
(41 \%)\end{array}$ & $\begin{array}{c}48 \% \\
(41 \%)\end{array}$ & $\begin{array}{c}77 \% \\
(48 \%)\end{array}$ \\
\hline $\begin{array}{l}\text { Obtained info. from a } \\
\text { gov. website }\end{array}$ & $\begin{array}{c}49 \% \\
(37 \%)\end{array}$ & $\begin{array}{c}45 \% \\
(37 \%)\end{array}$ & $\begin{array}{c}66 \% \\
(42 \%)\end{array}$ \\
\hline $\begin{array}{l}\text { Downloaded a form (for } \\
\text { submission) }\end{array}$ & $\begin{array}{c}39 \% \\
(26 \%)\end{array}$ & $\begin{array}{c}30 \% \\
(25 \%)\end{array}$ & $\begin{array}{c}41 \% \\
(29 \%)\end{array}$ \\
\hline $\begin{array}{l}\text { Submitted a complete } \\
\text { form (eService) }\end{array}$ & $\begin{array}{c}38 \% \\
(21 \%)\end{array}$ & $\begin{array}{c}30 \% \\
(21 \%)\end{array}$ & $\begin{array}{c}68 \% \\
(28 \%)\end{array}$ \\
\hline
\end{tabular}

Despite the fragmented online service offers (depending on the service areas), the data in Table 8 highlights that the Estonian usage of both private and public sector eServices are higher than the EU28 average on all parameters - and over time. With the exception of eCommerce, the use of eBanking and various forms of online interaction with public authorities are all between 12 and 40\%points higher in Estonia than the EU28 average in 2016. An interesting aspect is the percentage of Estonians using the internet $(85 \%)$ in 2016 . This is close to the number of citizens actively using eBanking (79\%), citizens who interact with government online $(79 \%)$ or use transactional eService's $(68 \%)$ - a stark contrast to the EU28 average but which mirrors the patterns of other successful eGovernment service providers like Denmark and the Netherlands $[39,41,43,57]$

\section{DISCUSSION AND CONCLUSIONS}

While Estonians household propensity to purchase of internet and citizens general use of the internet in Estonia (see Table 2) is similar to the EU28 average, the use of online banking services - which by concept are comparable to those of the government - is by comparison vastly higher in Estonia then for the EU28 average (see Table 8). This points to a number of influences related to eGovernance and inter-governmental cooperation.

Public awareness and channel strategies for public service delivery are directly related to eService take-up but seem to be influenced, both positively and negatively, by the eGovernance model, the level of cooperation and, the coordination between authorities in Estonia. First, the single national portal (www.eesti.ee) was launched in 2003, but the decision to channel users to a central portal is diluted by the launch of the rural municipality portal (www.kovtp.ee) in February 2011. The initial impact of cooperation on a single one-stop shop is thus eroded by a decision to deploy a second portal focusing on rural municipalities with no links to city municipalities or the national portal. Second, in the 3 years the author has been living in Tallinn, only a welcome letter has been sent to the eesti.ee mailbox which all Estonian ID numbers are born with. This indicating that authorities are not taking advantage of the portal and key infrastructure components which have the potential of creating a critical mass and usage of government online service offers akin to eBanking or has seen in the Danish eGovernment strategy 2012-2015 [39, 69, 70]. Third, while distributed responsibility is common in most countries, there seems to be a potential for further cooperation and compliance with the national eGovernment vision in Estonia. For instance, RISO is responsible for drafting and monitoring compliance with the national eGovernment vision, strategy and action plan, ITAO is responsible for service quality standard and the channel strategy choices, while RIA is running the national portal (www.eesti.ee ) and thus the most appropriate organization to ensure compliance with e.g. eService, single-sign-on, data and privacy standards. Similarly, the lack of letters, receipts and reminders sent to the national mailbox from authorities responsible for tax, pension, social services etc. points to a need for a more consolidated and joint-governmental approach to channel choices, online service delivery and re-use of key infrastructure components.

Roles, responsibilities and mandates are at times ambiguous in the Estonian approach to eGovernance and inter-governmental cooperation. For instance, who does the vision-network report to and which authority ensures that the network is consulted? On the strategic level, how proactive can MKM/RISO or the Government $\mathrm{CIO}$ and CIO network be visa-a-vis the ISC and the MKK/RISO, respectively?

With MKM/RISO being the responsible authority on the operational level, how strong is the mandate vis-a-vis the implementing thematic work groups and networks? Can the thematic work groups and networks side-step MKM/RISO by going directly to the government CIO or even the ISC or the cabinet office? Similar overlaps exist in relation to the thematic work groups and networks, as the government cabinet, the ISC and MKM/RISO all have the mandate to establish such daily implementation organs. While the CIO network represents a practical forum for decision making and problem solving in relation to daily implementation, its links to RISO and the ISC is fuzzy. This type of fragmentation is also exemplified in the existence of the Association of Estonian Cities and the Association of Municipalities in Estonia, both representing local authorities, albeit with different members.

It is clear that eGovernment and online service supply and use has been a success in the Estonian context. Pre-conditions like internet availability and the digital skills of citizens are in place. eServices, 
one-stop portals and key enablers, such as eID and digital signatures, have developed and rolled out in line with national strategic objectives, eGovernment strategies, and action plans. Citizens use of eServices is positive but following a slow start.

The success has been based on a tradition of politically driven and motivated public sector modernisation, a consensus seeking approach, trust between actors, informal networks and cooperation with the private sector $[49-51,54,62]$.

That said, the degree of cooperation between authorities and the level of integration between entities in the provision and production of services vary. Initial successes, such as the launch of eID and digital signatures (in cooperation with the private sector), and online tax applications provide new evidence in support of the positive role of inter-governmental cooperation play in the introduction and take-up of eService - as proposed by authors such as Heeks [5, 26], Lee \& Kwak [32] Chen \& Mingins [71].

Similarly, the less than optimal use joint infrastructure like the www.eesti.ee portal and digital postbox are an example of how benefit realization and value creation of ICT investments may not be maximized if authorities do not comply with, or support, key strategic objectives. Thus, the Estonian case highlights the importance of good management and coordination of government eGovernment activities in support of authors such as Davison [27], Iribarren et. al. [8], Janowski [28], Kalambokis et. al. [29], Shareef et. al. [30], Waseda [31] and organizations such as the OECD [72].

In conclusion, the Estonian case supports the initial question asked i.e. that that is a positive relationship between a strong cooperative eGovernance model (cause) and the introduction of online services (effect 1) and subsequent citizen use of the online service delivery channel (effect 2). That said, the Estonian experience also highlights the importance of a formal eGovernance model with clear and recognized mandates to ensure that decisions are made, conflicts are resolved, and the strategic visions, objectives and outcomes are achieved. For instance, the existence of a national CIO or specialized government entity for eGovernment does not guarantee success. The Estonian case shows the positive impact of informal and personal networks and the role of individuals in driving a vision, ensuring coordination and inter-governmental cooperation, but this also illustrates the potential risk of confusion and failure if there are overlapping or conflicting responsibilities and mandates in place. While successful, the Estonian approach to eGovernance and inter-governmental cooperation would benefit from a streamlining of potentially overlapping mandates and the formalisation of informal networks. This will help minimize the risk of failure if consensus cannot be reached, if personal and institutional capacities and contacts does not exist (or fail), e.g. in relation to social benefits and services, to authorities' compliance with strategic decisions, the use of joint infrastructure, but also current strategic focus areas such as data re-use, artificial intelligence, eService usability, and eParticipation.

\section{ACKNOWLEDGMENTS}

This paper is a result of the project "SmartEGOV: Harnessing EGOV for Smart Governance (Foundations, methods, Tools) / NORTE-01-0145-FEDER-000037”, supported by Norte Portugal Regional Operational Programme (NORTE 2020), under the PORTUGAL 2020 Partnership Agreement, through the European Regional Development Fund (EFDR). It was also supported in part by funding from Tallinn University of Technology, Project B42; OGI - Open Government Intelligence project in the EU Horizon 2020 framework program, grant agreement 693849.

\section{REFERENCES}

1. Bannister, F. and R. Connolly, Transformation and Public Sector Values, in $t$ Gov 11. 2011, Brunel University: London.

2. Brown, C.V. and S.L. Magill, Alignment of the IS functions with the enterprise: toward a model of antecedents. MIS quarterly, 1994: p. 371-403.

3. Brown, A.E. and G.G. Grant, Framing the frameworks: A review of IT governance research. Communications of the Association for Information Systems, 2005. 15(1): p. 38.

4. Cordella, A. and C.M. Bonina, A public value perspective for ICT enabled public sector reforms: A theoretical reflection. Government information quarterly, 2012. 29(4): p. 512-520.

5. Heeks, R., Implementing and managing eGovernment: an international text. 2005: Sage.

6. Pollitt, C. and G. Bouckaert, Public Management Reform: A comparative analysis-new public management, governance, and the Neo-Weberian state. 2011: Oxford University Press.

7. Klischewski, R. and H.J. Scholl, Information quality as capstone in negotiating e-government integration, interoperation and information sharing. Electronic Government, an International Journal, 2008. 5(2): p. 203-225.

8. Iribarren, M., et al., Capability maturity framework for eGovernment: A multi-dimensional model and assessing tool, in Electronic Government. 2008, Springer. p. 136-147.

9. Ross, J.W., P. Weill, and D. Robertson, Enterprise architecture as strategy: Creating a foundation for business execution. 2006: Harvard Business Press.

10. Poeppelbuss, J., et al., Maturity models in information systems research: literature search and analysis. Communications of the Association for Information Systems, 2011. 29(27): p. 505-532.

11. Heeks, R. and S. Bailur, Analyzing e-government research: Perspectives, philosophies, theories, methods, and practice. Government Information Quarterly, 2007. 24(2): p. 243-265.

12. Huijboom, N., et al., Public Services 2.0: the impact of social computing on public services, in Institute for Prospective Technological Studies, Joint Research Centre, European Commission. Luxembourg: Office for Official Publications of the European Communities. 2009: Luxembourg.

13. Traunmüller, R. and M.A. Wimmer, E-government at a decisive moment: sketching a roadmap to excellence, in Electronic Government. 2003, Springer. p. 1-14.

14. Millard, J.C., Luca; Galasso, Giovanna; Riedl, Reinhard Neuroni, Alessia C. ; Walser, Konrad; Sami Hamida, Andreas; Huijboom, Noor; Meyerhoff Nielsen, Morten; Leitner, Christine; and R.S. Fehlmann, European eGovernment 2005-2007: Taking stock of good practice and progress towards implementation of the 2010 eGovernment Action Plan. 2007. p. 80.

15. Christine Leitner, J.-M.E., François Heinderyckx, Klaus Lenk, Morten Meyerhoff Nielsen, Roland Traunmüller, eGovernment in Europe: The State of Affairs. 2003. p. 66.

16. Bannister, F., Dismantling the silos: extracting new value from IT investments in public administration. Information Systems Journal, 2001. 11(1): p. 65-84.

17. de Bri, F. and F. Bannister, Whole-of-government: The continuing problem of eliminating silos. Proceedings of the 
10th European Conference on eGovernment, National Centre for Taxation Studies and University of Limerick, Ireland, 2010: p. 122-133.

18. Janssen, M., Y. Charalabidis, and A. Zuiderwijk, Benefits, adoption barriers and myths of open data and open government. Information Systems Management, 2012. 29(4): p. 258-268.

19. Lips, M., E-government is dead: Long live public administration 2.0. Information Polity, 2012. 17(3): p. 239250 .

20. Meyerhoff Nielsen, M., Supply and use of citizen eServices: An analysis of selected national experiences in relation to existing governance and cooperation models. NISPAcee Journal of Public Administration and Policy, 2015. 23.

21. Bannister, F., The curse of the benchmark: an assessment of the validity and value of e-government comparisons. International Review of Administrative Sciences, 2007. 73(2): p. 171-188.

22. Andersen, K.V. and H.Z. Henriksen, E-government maturity models: Extension of the Layne and Lee model. Government information quarterly, 2006. 23(2): p. 236-248.

23. Meyerhoff Nielsen, M., The Role of Governance, Cooperation, and eService Use in Current eGovernment Stage Models. 2016: Hawaii.

24. Pöppelbuß, J. and M. Röglinger. What makes a useful maturity model? a framework of general design principles for maturity models and its demonstration in business process management. in ECIS. 2011.

25. Meyerhoff Nielsen, M., Governance failure in light of Government 3.0: Foundations for building next generation eGovernment maturity models, in Government 3.0 - Next Generation Government Technology Infrastructure and Services - Opportunities, Enabling Technologies, Challenges and Roadmaps, A.M. Ojo, Jeremy, Editor. FORTHCOMING 2017, PAIT - Public Administration and Information Technology,.

26. Heeks, R., A better eGovernment maturity model, in iGovernment Briefing. 2015, University of Manchester: Manchester.

27. Davison, R.M., C. Wagner, and L.C. Ma, From government to e-government: a transition model. Information Technology \& People, 2005. 18(3): p. 280-299.

28. Janowski, T., Digital government evolution: From transformation to contextualization. Government Information Quarterly, 2015.32(3): p. 221-236.

29. Kalampokis, E., E. Tambouris, and K. Tarabanis, Open government data: a stage model, in Electronic government. 2011, Springer. p. 235-246.

30. Shareef, M.A., et al., e-Government Adoption Model (GAM): Differing service maturity levels. Government Information Quarterly, 2011.28(1): p. 17-35.

31. Obi, T., WASEDA - IAC Internationl e-Government Index. 2015, Waseda University and IAC International Agency of CIO Tokiyo.

32. Lee, G. and Y.H. Kwak, An open government maturity model for social media-based public engagement. Government Information Quarterly, 2012. 29(4): p. 492-503.
33. Chen, J.Y., Y.; Mingins, C. . A Three-Dimensional Model for E-Government Development with Cases in China's Regional E-Government Practice and Experience. in ICMeCG, 2011 Fifth International Conference on Management of eCommerce and e-Government. 2011. Wuhan: The Institute of Electrical and Electronics Engineers Inc. .

34. UNDESA -United Nations Department of Economic and Social Affairs, E-Government Survey 2014: E-Government for the future we want. 2014, United Nations: New York.

35. Benbasat, I., D.K. Goldstein, and M. Mead, The case research strategy in studies of information systems. MIS quarterly, 1987: p. 369-386.

36. Rohlfing, I., Case Studies and Causal Inference: an integrative framework. 2012: Palgrave Macmillan.

37. Yin, R.K., Case study research: Design and methods. 2013: Sage publications.

38. Nielsen, M.M. Digitising a small island state: A lesson in Faroese. in Proceedings of the 9th International Conference on Theory and Practice of Electronic Governance. 2016. ACM.

39. Meyerhoff Nielsen, M. Governance and Online Service Delivery: The Danish Case. in 15th IFIP Electronic Government (EGOV) and 8th Electronic Participation (ePart) Conference 2016. 2016. Guimarães: IOS Press.

40. Meyerhoff Nielsen, M. Georgia on my mind: A study of the role of governance and cooperation in online service delivery in the Caucasus. in 16th IFIP WG 8.5 International Conference, EGOV 2017, St. Petersburg, Russia, September 4-7, 2017, Proceedings. FORTHCOMING 2017. St. Petersburg: Springer.

41. Meyerhoff Nielsen, M., eGovernment and Governance: The Danish-Japanese timelines and models compared. CeDEM Asia 2012, 2016: p. 53-66.

42. Collier, D. and J. Mahoney, Insights and pitfalls: Selection bias in qualitative research. World Politics, 1996. 49(01): p. 56-91.

43. Eurostat. Information society household survey. 2016 [cited 201629 June 2016]; Available from:

http://ec.europa.eu/eurostat/web/informationsociety/data/database.

44. ITU - Internet Telecommunications Union. Worlds Telecommunication / ICT Indicators Database. 2014; Available from: http://www.itu.int/en/ITUD/Statistics/Pages/publications/wtid.aspx.

45. UNDESA - United Nations Department of Economic and Social Affairs, E-Government Survey 2010: Leveraging egovernment at a time of financial and economic crisis. 2010, United Nations: New York.

46. UNDESA - United Nations Department of Economic and Social Affairs, E-Government Survey 2012: E-Government for the people. 2012, United Nations: New York.

47. CIA - Central Intelligence Agency. The World Factbook. 20151 July 2014 [cited 20151 October]; Available from: https://www.cia.gov/library/publications/the-worldfactbook/rankorder/2119rank.html.

48. Charles, A., The electronic state: Estonia's new media revolution. Journal of Contemporary European Research, 2009. 5(1): p. 97-113. 
49. Kitsing, M., Success Without Strategy: E-Government Development in Estonia. Policy \& Internet, 2011. 3(1): p. 121.

50. Kalvet, T., Innovation: a factor explaining e-government success in Estonia. Electronic Government, an International Journal, 2012. 9(2): p. 142-157.

51. Ernsdorff, M. and A. Berbec, 12 Estonia. E-government in Europe: Re-booting the State, 2006: p. 171.

52. MKM - Ministry of Economic Affairs and Communication. Information Society. 2017 [cited 201727 January 2017]; Available from: https://www.mkm.ee/en/objectivesactivities/information-society.

53. JoinUP, eGovernment in Estonia, February 2016, Edition 18.0. 2016, EC - European Commission: Brussels.

54. OECD, OECD Public Governance Reviews: Estonia Towards a Single Government Approach. 2011, OECD: Paris.

55. MKM - Ministry of Economic Affairs and Communication, Digital Agenda 2020 for Estonia. 2013, MKM - Ministry of Economic Affairs and Communication: Tallinn.

56. Kitsing, M. Explaining the e-government success in Estonia. in Proceedings of the 2008 international conference on Digital government research. 2008. Digital Government Society of North America.

57. Nielsen, M.M., E-governance and stage models: analysis of identified models and selected Eurasian experiences in digitising citizen service delivery. IJEG - International Journal of Electronic Government,, 2016. 12(2): p. 107-141.

58. UNDESA - United Nations Department of Economic and Social Affairs, E-Government Survey 2008: From egovernment to connected government. 2008, United Nations: New York.

59. Heeks, R., Understanding and measuring eGovernment: international benchmarking studies. UNDESA workshop,"EParticipation and E-Government: Understanding the Present and Creating the Future", Budapest, Hungary, 2006: p. 27-28.

60. Meyerhoff Nielsen, M. and K. Bagarukayo, The role of governance in the supply and take-up of government eServices: The case of Kenya, Uganda, Rwanda and South
Africa, in Catalyzing Development through ICT Adaption: The Developing World Experience, H.L. Kaur, Ewa; Marszk Adam, Editor. Forthcoming, Springer: New York City.

61. CCRE-CEMR. CEMR in Estonia. 2017 [cited 20171 February 2017]; Available from: http://www.ccre.org/en/pays/view/16.

62. OECD, OECD Public Governance Reviews: Estonia Fostering Strategic Capacity across Governments and Digital Services across Borders. 2015, OECD: Paris.

63. Sikurt, S., Estonian eGovernment organigram, M.M. Nielsen, Editor. 2016, N/A: Private.

64. Riigikantselei. E-Estonia Council. 2017 [cited 201726 January 2017]; Available from: https://riigikantselei.ee/en/supporting-government/e-estoniacouncil.

65. ID. Statistics. 2017 [cited 20171 February 2017]; Available from: http://www.id.ee/?lang=en.

66. Areng, L., eesti.ee data, M.M. Nielsen, Editor. 2017: Private.

67. Rozow, J., Data on volume of online tax returns M.M. Nielsen, Editor. 2016, Private: Private.

68. RIA - Information Systems Authority. Portal in numbers. 2017 [cited 20171 February 2017]; Available from: https://www.eesti.ee/eng/topics/business/riigiportaali abi/part nerile $1 /$ portal in numbers

69. Meyerhoff Nielsen, M., The use, the service and the Danish approach to online user-friendliness. Pro Publico BonoPublic Administration, 2016. Forthcoming.

70. DIGST - Digitaliseringsstyrlesne, The digital path to future welfare: Joint national eGovernment strategy 2011-2015. 2011, DIGST -Digitaliseringsstyrelsen: Copenhagen.

71. Chen, J.Y., Y.; Mingins, C., A Three-Dimensional Model for E-Government Development with Cases in China's Regional E-Government Practice and Experience. ICMeCG, 2011 Fifth International Conference on Management of eCommerce and e-Government, 2011: p. 113-120.

72. OECD, Recommendation of the Council on Digital Government Strategies 15 July 2014 - C(2014)88. 2014, OECD: Paris. 